ORIGINAL ARTICLE

\title{
GAMBARAN INDEKS LARVA AEDES AEGYPTI DI BUFFER WILAYAH KERJA BANDARA SEPINGGAN BALIKPAPAN
}

\author{
,Abdurrakhman \\ Fakultas Kesehatan Masyarakat Universitas Airlangga, Surabaya, Indonesia \\ *Correspondent Author: aboeraja80@gmail.com
}

\section{ARTICLE INFO}

Article history:

Received 25 January 2019

Received in revised form

February 2019

Accepted 4 February 2019

\section{Keywords: \\ Larva density, \\ Breeding sites, \\ Eradicatioan Behavior \\ Mosquito Levels and \\ larvasidation}

\section{Kata Kunci:}

Kepadatan Jentik, Tempat perindukan, Perilaku Pemberantasan Sarang Nyamuk dan larvasidasi.

\begin{abstract}
The House index and Container Index in the buffer area of the working area of Balikpapan Sepinggan Airport is still above 1\%, so the potential for the spread of dengue disease. Mobilization of people, goods and transportation equipment will increasingly affect the transmission of disease in ports and airports, especially for vector-borne diseases. This study aims to analyze the risk factors associated with larvae density of Aedes aegypti and describe the larvae index in the buffer zone of the Sepinggan Balikpapan Airport This study was a descriptive study with a cross sectional design. The sample in this study was 121 houses with a proportionate stratified random sampling, the research location was in the buffer zone of Sepinggan Balikpapan Airport in November 2018. The variables studied were houses with positive larvae containers, breeding sites and PSN behavior and larvasidation. The data was analyzed using the chi square test. There was a relationship between houses with larvae positive Aedes aegypti, behavior of Mosquito Nest Eradication (PSN) and larvasidation with larvae density of Aedes aegypti but not for breeding sites ( $\mathrm{p}$ $=0.00$ and $95 \% \mathrm{CI}=0.64)$, and $(\mathrm{p}=0.00$ and $95 \% \mathrm{CI}=0.34)$. The description of several Aedes aegypti larvae index, namely House Index $(\mathrm{HI})=57.02 \%$, Container Index $(\mathrm{CI})=24.36 \%$, Bruteau Index $(\mathrm{BI})=148.76$, and Flick Free Numbers $(\mathrm{ABJ})=42.98 \%$. Houses with larvae of Aedes aegypti larvae and PSN and larvasidation behavior were associated with larvae density of Aedes aegypti. The index of HI, CI and BI larvae is of high value so there is a risk of DBD transmission.
\end{abstract}

\begin{abstract}
ABSTRAK
House index dan Container Index di buffer wilayah kerja Bandara Sepinggan Balikpapan masih diatas $1 \%$, sehingga berpotensi penyebaran penyakit DBD. Mobilisasi orang, barang serta alat angkut semakin meningkat akan berpengaruh terhadap penularan penyakit di pelabuhan dan bandara terutama untuk penyakit tular vektor. Penelitian ini bertujuan untuk menganalisis faktor risiko yang berhubungan dengan kepadatan jentik Aedes aegypti dan mendeskripsikan indeks larva di buffer wilayah kerja Bandara Sepinggan Balikpapan Penelitian ini merupakan penelitian deskriptif dengan desain cross sectional. Sampel pada penelitian ini adalah 121 rumah dengan proportionate stratified random sampling, lokasi penelitian di buffer wilayah kerja Bandara Sepinggan Balikpapan pada bulan november 2018. Variabel yang diteliti, rumah dengan kontainer positif jentik, tempat perindukan dan perilaku PSN dan larvasidasi.Data dianalisa meggunakan uji statistik chi square.Hasil penelitian ada hubungan antara rumah dengan kontainer positif jentik Aedes aegypti, perilaku Pemberantasan Sarang Nyamuk (PSN) dan larvasidasi dengan kepadatan jentik Aedes aegypti tetapi tidak untuk tempat perindukan, $(p=0,00$ dan $95 \% \mathrm{CI}=0,64)$, dan $(p=0,00$ dan $95 \% \mathrm{CI}=0,34)$. Gambaran beberapa indeks jentik Aedes aegypti yaitu House Index $(\mathrm{HI})=57,02 \%$,
\end{abstract}


Container Index $(\mathrm{CI})=24,36 \%$, Bruteau Index $(\mathrm{BI})=148,76$, dan Angka Bebas Jentik $(\mathrm{ABJ})=42,98 \%$. Kesimpulan rumah dengan kontainer positif jentik Aedes aegypti dan perilaku PSN dan larvasidasi berhubungan dengan kepadatan jentik Aedes aegypti. Indeks larva HI, CI dan BI nilainya tinggi sehingga berisiko terjadi penularan DBD.

@ 2019 Medical and Health Science Journal. 10.33086/mhsj.v3i1.924

\section{PENDAHULUAN}

Penyakit demam berdarah dapat menyebabkan kematian pada penderita dalam waktu singkat. Demam Berdarah Dengue (DBD) merupakan penyakit infeksi dengan penyebab salah satu dari 4 virus dengue berbeda dan ditularkan melalui vektor nyamuk terutama Aedes aegypty dan Aedes albopictus yang tersebar di daerah tropis dan subtropis salah satunya kepulauan di Indonesia (Vyas, 2013).

Diperkirakan 500.000 orang dengan demam berdarah parah memerlukan rawat inap setiap tahun, dan dengan perkiraan 2,50\% kasus kematian setiap tahun. Secara global, 28\% penurunan dalam kasus kematian telat tercatan antara tahun 2010 dan 2016 dengan peningkatan yang signifikan dalam manajemen kasus melalui peningkatan kapasitas di tingkat negara(Kemenkes RI, 2018b).

Perjalanan udara internasional yang cepat memungkinkan wisatawan terinfeksi untuk tiba di tempat tujaan selama masa viremia, yang bisa bertahan hingga 5 hari setelah onset penyakit. Sementara nyamuk Aedes invasif yang ada di bandara setempat mungkin menggigit seorang wisatawan dan menjadi terinfeksi(Semenza et al., 2014).

Penyakit Demam Berdarah Dengue (DBD) masih merupakan salah satu masalah kesehatan masyarakat yang utama di Indonesia. Jumlah penderita dan luar daerah penyebarannya semakin bertambah seiring dengan meningkatnya mobilitas dan kepadatan penduduk (Kemenkes RI, 2010).

Tahun 2014 sampai dengan 2016 di Balikpapan terjadi kenaikan inciden rate dimana tahun 2014 terdapat 2.176 kasus dengan IR 343,64 dan CFR 0,64. Tahun 2015 terdapat 2.145 kasus dengan IR 348,48, dan CFR 1,17, kemudian di tahun 2016 terdapat 2.508 kasus dengan IR 382,30 dan CFR 1,00. Tahun 2017 terdapat kasus 1.137 dengan IR 178,77 CFR 0.18 dan Tahun 2018 sampai dengan bulan September 2018 terdapat kasus 790 dengan IR 122,34 CFR 0,25 (Dinas Kesehatan Kota Balikpapan, 2016).

Bandara Sultan Aji Muhammad Sulaiman Balikpapan merupakan bandara internasional yang berada di wilayah Kota Balikpapan merupakan pintu keluar masuk dan berkumpulnya orang dengan jumlah penumpang datang dan pergi rata rata 20.924 orang/hari pada bulan April tahun 2018 (PT Angkasa Pura I, 2018).

Jumlah pergerakan orang di bandara yang tinggi dapat meningkatkan risiko penularan dan penyebaran penyakit baik penyakit yang menular langsung antar manusia maupun penyakit yang ditularkan oleh vektor/serangga penular penyakit seperti Demam Berdarah Dengue (DBD) sangat besar dan dapat menimbulkan wabah atau KLB yang berpotensi menimbulkan Kedaruratan Masalah Kesehatan Masyarakat yang meresahkan Dunia (KKMD) atau Public Health Emergency of International Concern (PHEIC) (Kemenkes RI, 2014).

Pengamatan vektor nyamuk Aedes sp di buffer wilayah kerja Bandara Sepinggan Balikpapan dilakukan oleh Kantor Kesehatan Pelabuhan Kelas II Balikpapan meliputi wilayah disekitar Bandara (buffer area) dan pengamatan pada perimeter area bandara meliputi bangunan bandara dan sarana prasarana yang ada di dalamnya (KKP Kelas II Balikpapan, 2017). 
House Indeks (HI) dan Container index (CI) merupakan indikator keberadaan jentik Aedes aegypti. HI dan CI di buffer wilayah kerja Bandara Sepinggan Balikpapan masih di atas 1\%, meskipun sudah dilakukan program pengawasan dan pengendalian vektor oleh Kantor Kesehatan Pelabuhan Kelas II Balikpapan di wilayah kerja Bandara Sepinggan Balikpapan. Rata - Rata House index pada tahun 2014, 26,12\%, tahun 2015 $1,78 \%$, tahun $2016173,25 \%$, tahun 2017 22,49\%(Kemenkes RI, 2018a). House Indeks (HI) yang lebih dari $1 \%$ berpotensi mempengaruhi kepadatan jentik Aedes aegypti, sehingga diperlukan upaya pemutusan rantai penularan penyakit untuk menurunkan kepadatan jentik dengan cara pengendalian jentik. Persyaratan House IndeksAedes aegypti untuk wilayah perimeter adalah $0 \%$ dan untuk wilayah buffer adalah < 1\% (Depkes RI, 2009)

Kasus demam berdarah dengue di Kelurahan Sepinggan Raya Balikpapan yang berdekatan dengan wilayah kerja Bandara Sepinggan Balikpapan tahun 2015 dari 343 kasus dengan kematian 1 orang. Pada tahun 2016 terdapat 597 kasus dengan kematian 3 orang, Tahun 2017 jumlah kasus 148 meninggal 0 orang. (Dinas Kesehatan Kota Balikpapan, 2016).

Tujuan penelitian ini adalah menganalisis faktor risiko yang berhubungan dengan kepadatan jentik Aedes egypti dan mendeskripsikan indeks larva di buffer wilayah kerja Bandara Sepinggan Balikpapan.

\section{METODE PENELITIAN}

Rancangan penelitian yang akan dilakukan dalam penelitian ini adalah penelitian deskriptif, dengan desain yang dilakukan menurut waktunya adalah cross sectional. Populasi dalam penelitian ini adalah seluruh (rumah/gedung) yang berada di RT 03, RT 04, RT 11 dan RT 12 Kelurahan Sepinggan Raya Balikpapan buffer wilayah kerja
Bandara Sepinggan Balikpapan, adapun sebagai objek penelitian adalah jentik dari nyamuk Aedes aegypti sebagai penular penyakit demam berdarah. Teknik pengambilan sampel yang digunakan adalah proportionate stratified random sampling sebanyak 121 sampel.

Penelitian ini akan dilaksanakan di buffer Wilayah Kerja Kantor Kesehatan Pelabuhan Kelas II Balikpapan yaitu buffer Bandara Sepinggan Balikpapan Kalimantan Timur. Waktu penelitian dilaksanakan pada bulan November 2018.

Teknik pengumpulan data primer melaluiwawancara, kuisioner, pengamatan langsung dan survei dengan single larva secara visual pada kontainer-kontainer sedangkan data sekunder melalui Institusi yaitu Kantor Kesehatan Pelabuhan (KKP) Kelas II Balikpapan di seksi pengendalian risiko lingkungan. Variabel bebas yang diteliti adalah rumah dengan kontainer positif jentik Aedes aegypti, tempat perindukan, perilaku PSN dan larvasidasi.Variabel terikat yang diteliti adalah kepadatan jentik Aedes aegypti.Penelitian ini telah mendapatkan persetujuan etik No: 554/EA/KEPK/2018.

Analisis univariabel dilakukan untuk mengetahui gambaran distribusi frekuensi dan proporsi dari masing -masing variabel dependen dan indipenden dengan tujuan untuk memperoleh gambaran distribusi frekuensi dan analisis bivariabel digunakan adalah uji statistik chi square $(\alpha=0,05 \%)$.

\section{HASIL DAN PEMBAHASAN \\ HASIL \\ Gambaran Umum Tempat Penelitian}

Secara umum wilayah kerja Bandara Sepinggan Balikpapan terbagi dalam dua area yaitu perimeter area dan buffer area. Perimeter area merupakan wilayah dengan jarak 100 meter dari apron bandara tempat untuk menurunkan dan menaikkan penumpang maupun tempat parkir 
pesawat yang meliputi sarana dan prasarana seperti perkantoran, terminal keberangkatan dan terminal kedatangan penumpang, terminal kargo, hanggar pesawat, hotel, mesjid dan lain lain. Buffer area adalah daerah disekitar perimeter dengan jarak 400 meter dari perimeter area merupakan daerah peyangga, terdiri dari hotel -hotel, perkantoran dan sekitar 30\% terdiri dari perkampungan penduduk yang padat dan berpotensial sebagai tempat perindukan Vektor DBD.

\section{Gambaran Rumah dengan Kontainer Positif jentik Aedes aegypti}

Rumah dengan kontainer positif jentikAedes aegypti dikategorikan menjadi dua yaitu ada dan tidak ada. Rumah dengan kontainer positif jentik Aedes aegypti ditemukan sebanyak 57\% dan yang tidak ada ditemukan kontainer positif Aedesaegypti 43\%.Rata - rata rumah memiliki lebih dari 1 tempat penampungan air.

Tabel 1. Distribusi Rumah dengan Kontainer Positif Jentik Aedes aegypti

\begin{tabular}{|c|c|c|}
\hline $\begin{array}{c}\text { Kontainer Positif } \\
\text { Jentik }\end{array}$ & $\begin{array}{l}\text { Jumlah } \\
\text { (n) }\end{array}$ & Persentase \\
\hline$\overline{\text { Ada }}$ & 69 & 57 \\
\hline Tidak Ada & 52 & 43 \\
\hline Total & 121 & 100 \\
\hline
\end{tabular}

Tabel 2. Distribusi Pengamatan Tempat Perindukan Jentik Aedes aegypti

\begin{tabular}{clll}
\hline $\begin{array}{c}\text { Tempat } \\
\text { perindukan }\end{array}$ & (n) & Jumlah & Persentase \\
\hline Ada & 121 & 100 \\
Tidak ada & 0 & 0 \\
\hline Total & 121 & 100 \\
\hline
\end{tabular}

\section{Jenis Tempat Perindukan}

Jenis tempat perindukan nyamuk yang terdapat di dalam rumah saja maupun di dalam dan diluar rumah responden dibedakan menjadi Tandon, Bak mandi/WC, Tempayan, Drum, Ember dan lain-lain. Tempat perindukan sebanyak 739 kontainer dengan keberadaan jentik terdapat pada
180 kontainer. Dengan di dominasi drum sebagai tempat paling banyak ditemukan jentik (79 kontainer) dan paling sedikit adalah tempat minum burung (1 kontainer). Drum lebih disukai masyarakat karena kapasitas penampungan airnya cukup besar \pm 200 liter. Selain digunakan untuk keperluan sehari-hari, juga digunakan sebagai tempat penampungan cadangan air.

Tabel 3. Distribusi Pengamatan Jenis Tempat Perindukan Jentik Aedes aegypti

\begin{tabular}{|c|c|c|c|}
\hline $\begin{array}{l}\text { Jenis Tempat } \\
\text { Perindukan }\end{array}$ & Diperiksa & $\begin{array}{l}\text { Ada } \\
\text { Jentik }\end{array}$ & $\begin{array}{l}\text { Tidak } \\
\text {-Ada }\end{array}$ \\
\hline Tandon & 92 & 6 & 86 \\
\hline Bak mandi/WC & 90 & 24 & 66 \\
\hline Tempayan & 58 & 11 & 47 \\
\hline Drum & 254 & 79 & 175 \\
\hline Ember & 231 & 46 & 185 \\
\hline $\begin{array}{l}\text { Air tampungan } \\
\text { kulkas }\end{array}$ & 3 & 3 & 0 \\
\hline $\begin{array}{l}\text { Air tampungan } \\
\text { dispenser }\end{array}$ & 2 & 2 & 0 \\
\hline $\begin{array}{l}\text { Kaleng cat } \\
\text { bekas }\end{array}$ & 6 & 6 & 0 \\
\hline Ban bekas & 2 & 2 & 0 \\
\hline $\begin{array}{l}\text { Tempat minum } \\
\text { burung }\end{array}$ & 1 & 1 & 0 \\
\hline Total & 739 & 180 & 559 \\
\hline
\end{tabular}

\section{Perilaku PSN dan Larvasidasi}

Pemberantasan sarang nyamuk dan larvasidasi merupakan salah satu tindakan pencegahan penyebaran penyakit DBD.Kegiatan ini merupakan kegiatan yang dapat dilakukan oleh masyarakat secara mandiri dan berkesinambungan. Hasil observasi dilapangan didapatkan perilaku PSN dan larvasidasi yang baik sebanyak 27 reponden atau $22,30 \%$, hasil kurang 94 responden $77,70 \%$.

Tabel 4.

Distribusi Perilaku PSN dan Larvasidasi

\begin{tabular}{lcc}
\hline Diperiksa & Jumlah & \multicolumn{2}{c}{$\begin{array}{c}\text { Perilaku PSN dan } \\
\text { Larvasidasi }\end{array}$} \\
\cline { 2 - 3 } & \multicolumn{2}{c}{ Baik $\quad$ Kurang } \\
\cline { 2 - 3 } & \multicolumn{2}{c}{$\%$ n \% } \\
\hline Rumah & $1212722,309477,70$ \\
\hline
\end{tabular}




\section{Kepadatan Jentik Aedes aegypti}

Hasil Kepadatan Jentik Aedes aegypti didapatkan, rendah sebesar $51,20 \%$ dan tinggi sebesar $48,80 \%$.
Tabel 5.

Distribusi Kepadatan Jentik Aedes aegypti

\begin{tabular}{lrr}
\hline $\begin{array}{l}\text { Kepadatan Jentik } \\
\text { Aedes aegypti }\end{array}$ & \multicolumn{1}{c}{$\begin{array}{c}\text { Jumlah } \\
(\mathrm{n})\end{array}$} & \multicolumn{1}{c}{$\begin{array}{c}\text { Persentase } \\
(\%)\end{array}$} \\
\hline Rendah & 62 & 51,20 \\
Tinggi & 59 & 48,80 \\
\hline Total & 121 & 100,00 \\
\hline
\end{tabular}

Tabel 6.

Analisis Hubungan Antara Rumah dengan Kontainer Positif Jentik Aedes aegypti, Tempat Perindukan, ,Tindakan PSN dan Larvasidasi

\begin{tabular}{|c|c|c|c|c|c|}
\hline \multirow[t]{2}{*}{ Variabel } & \multicolumn{3}{|c|}{ Kepadatan Jentik } & \multirow[b]{2}{*}{$\mathbf{P}$} & \multirow{2}{*}{$\begin{array}{l}\text { Nilai } \\
\text { KK }\end{array}$} \\
\hline & $\begin{array}{c}\text { Rendah } \\
\text { n }\end{array}$ & $\begin{array}{c}\text { Tinggi } \\
\mathbf{n}\end{array}$ & Total & & \\
\hline \multicolumn{6}{|c|}{ Rumah dengan Kontainer Positif Jentik Aedes aegypti } \\
\hline Ada & 11 & 58 & 69 & & \\
\hline Tidak Ada & 51 & 1 & 52 & $* 0,00$ & 0.64 \\
\hline Total & 62 & 59 & 121 & & \\
\hline \multicolumn{6}{|c|}{ Tempat Perindukan } \\
\hline Ada & 63 & 58 & 121 & & \\
\hline Total & 63 & 58 & 121 & & \\
\hline \multicolumn{6}{|c|}{ Tindakan PSN dan Larvasidasi } \\
\hline Baik & 23 & 4 & 27 & & \\
\hline Kurang & 39 & 55 & 94 & $* 0,00$ & 0,34 \\
\hline Total & 62 & 59 & 121 & & \\
\hline *signifikan & & & & & \\
\hline
\end{tabular}

\section{PEMBAHASAN}

\section{Rumah dengan Kontainer Positif Jentik Aedes aegypti}

Keberadaan jentik Aedes aegypti merupakan indikator dari potensi keterjangkitan masyarakat akan penyakit yang ditularkan oleh nyamuk seperti DBD, Chikungunya dan zika. Hal ini sesuai dengan teori (Nadesul, 2016) bahwa jika jentik nyamuk Aedes aegypti dibiarkan hidup, maka akan menambah banyak populasi nyamuk pembawa penyakit yang ditularkan oleh nyamuk tersebut.

Hasil Observasi keberadaaan jentik Aedes aegypti dari 121 rumah yang dilakukan pemeriksaan di dapatkan House Index (HI) sebesar 57\%, Container Index (CI) 24,36\%, Breteau Index 148,76 dan Angka Bebas Jentik didapatkan 42,98 $\%$ serta Density Figure dilihat dari nilai Container indeks nilainya ada 6. Daerah - daerah dengan densitas figure diatas 5 (Breteau Indexdiatas 50) besar sekali kemungkinan transmisi penyakit demam kuning (urban yellow fever), sedangkan daerah - daerah dengan density figure 1 (Breteau Index dibawah 5) kemungkinan transmisi demam kuning dianggap kecil sekali (Depkes RI, 2009).

Kondisi ini menunjukkan bahwa kepadatan nyamuk di buffer area Bandara Sultan Aji Muhammad Sulaiman Sepinggan Balikpapan tinggi karena untuk House Index (HI), Container Index (CI) dan Breteau Index (BI) di buffer area bandara $>1$ sehingga wilker bandara Sultan Aji Muhammad Sulaiman Sepinggan Balikpapan mempunyai risiko transmisi nyamuk yang cukup tinggi untuk terjadinya penularan penyakit yang ditularkan oleh nyamuk. waktu penelitian dilakukan pada awal musim hujan. Curah hujan menambah genangan air sebagai tempat perindukan, dan kelembapan udara terutama untuk daerah pantai. kelembapan udara di daerah pantai 
akan menambah jarak terbang nyamuk dan umur nyamuk (Kemenkes RI, 2013).

\section{Hubungan Rumah dengan kontainer positif jentik Aedes aegypti dengan kepadatan jentik Aedes aegypti \\ Hasil penelitian menunjukan adanya} hubungan yang signifikan antara kontainer dengan jentik Aedes aegypti dengan kepadatan jentik nyamuk Aedes aegypti di buffer area wilker bandara Sultan Aji Muhammad Sulaiman Sepinggan Balikpapan.Dari 739 kontainer yang di periksa terdapat 180 kontainer yang positif ada jentik Aedes aegypti.Di dapatkan hasil Container Index (CI) $24,36 \%$ dan bila dihubungkan dengan tabel density figure didapatkan hasil density figure di skala 6. Bila tingkat kepadatan berada pada skala 6-9 berarti kepadatan tinggi. Semakin banyak jumlah kontainer dalam satu rumah memberikan lebih banyak peluang bagi Aedes aegypti untuk berkembang biak di rumah tersebut. (Prasetyowati \& Ginanjar, 2017).

\section{Hubungan antara tempat perindukan dan kepadatan jentik Aedes aegypti}

Tidak terdapat hubungan secara signifikan dengan kepadatan jentik Aedes aegypti.Hasil penelitian menunjukkan bahwa tempat perindukan ditemukan di semua rumah responden. Berbeda dengan yang dilakukan (Nani, 2016) bahwa responden yang memiliki tempat penampungan di dalam dan diluar rumah mempunyai resiko lebih besar terhadap keberadaan jentik Aedes egypti.

\section{Hubungan Perilaku PSN dan Larvasidasi dengan Kepadatan Jentik Aedes aegypti}

Hasil penelitian menunjukkan ada hubungan yang signifikan antara perilaku PSN dan larvasidasi dengan kepadatan Aedes aegypti dengan p value sebesar 0,00 dimana $(\rho<\alpha)$. Hal ini selaras dengan penelitian (Septianto, 2014)yang menunjukkan bahwa ada hubungan antara menguras tempat keberadaan larva Aedes aegypti. Pengurasan pada tempat penampungan air minimal seminggu sekali dapat mengurangi tempat berkembang biak jentik Aedes aegypti. Nyamuk betina dewasa meletakkan telurnya di dinding kontainer diatas permukaan air. Bila kena air akan menetas menjadi jentik, setelah 5 - 10 hari larva akan menjadi pupa dan 2 hari kemudian pupa akan menetas menjadi dewasa (Kemenkes RI, 2013). Juga selaras dengan penelitian Desniawati (2014) yang menunjukkan bahwa menguras tempat penampungan air, mengubur barang bekas, memperbaiki saluran talang air berhubungan signifikan dengan keberadaan larva Aedes aegypti. Hal ini juga selaras dengan penelitian Novitasari \& Sugiyanto (2014) yang dilakukan di RW 01 Kelurahan Sendangguwo Semarang yang menyatakan ada hubungan yang signifikan antara praktik PSN dengan keberadaan jentik Aedes aegypti dengan nilai $\rho=0,03$.

\section{Gambaran Indeks Jentik di Buffer Wilayah Kerja Sepinggan Balikpapan}

Hasil pengamatan dan observasi di rumah responden di dapatkan rumah yang terdapat jentik sebanyak 69 rumah dan tidak terdapat jentik sebanyak 52 buah. Jumlah kontainer yang diperiksa sebanyak 739 kontainer dengan kontainer positif jentik Aedes aegypti sebanyak 180 kontainer. Maka dari hasil tersebut dapat diperoleh indek $\mathrm{HI}=57 \%$, $\mathrm{CI}=24,36 \%, \mathrm{BI}=148,7$ dan $\mathrm{ABJ}=42,98 \%$. Hasil indeks larva tersebut melebihi ambang batas yang dipersyaratkan untuk buffer area yaitu $\mathrm{HI}<1 \%$. Bila HI mencapai atau melebihi $1 \%$ dan BI melebihi 50 maka harus dilakukan pengendalian jentik Aedes aegypti.

Praptowibowo (2015) House index (HI) merupakan indikator yang paling sering digunakan untuk monitoring infestasi nyamuk. Akan tetapi house index termasuk lemah dalam risiko penularan penyakit karena tidak menghitung tempat penampungan air atau kontainer dan data rumah yang positif dengan larva, jumlah nyamuk yang sebenarnya tinggal juga tidak diketahui di rumah tersebut. 
Nilai CI dapat digunakan sebagai pembanding untuk evaluasi pogram pengendalian vektor tetapi tidak berguna dari sisi epidemiologis. Nilai BI menunjukkan hubungan antara kontainer yang positif dengan jumlah rumah dan indeks ini dianggap indeks yang paling baik tetapi tidak mencerminkan jumlah larva dalam kontainer.BI mempunyai nilai signifikan epidemiologis yang lebih besar.

\section{KESIMPULAN}

Ada hubungan antara rumah dengan kontainer positif jentik Aedes aegypti, Perilaku PSN dan larvasidasi dengan kepadatan Jentik Aedes aegypti, tetapi tidak untuk tempat perindukan di buffer wilayah kerja Bandara Sepinggan Balikpapan Tahun 2018. Indeks larva jentik Aedes aegypti di buffer wilayah kerja Sepinggan Balikpapan didapatkan hasil yang tinggi. Hal ini menunjukkan buffer wilker Bandara Sepinggan Balikpapan berpotensi untuk penularan Demam Berdarah Dengue.

\section{DAFTAR PUSTAKA}

1. Depkes RI. (2009). Standar Operasional Prosedur Kegiatan Kantor Kesehatan Pelabuhan di Pintu Masuk Negara. Jakarta.

2. Desniawati, F. (2014). Pelaksanaan 3M Plus Terhadap Keberadaan Larva Aedes aegypti di Wilayah Kerja Puskesmas Ciputat Kota Tanggaerang Selatan Bulan Mei-Juni Tahun 2014. Jakarta.

3. Dinas Kesehatan Kota Balikpapan. (2016). Profil Dinas Kesehatan Kota Balikpapan. Balikpapan.

4. Kemenkes RI. (2010). Buletin Jendela Epidemiologi.

5. Kemenkes RI. Peraturan Menkes RI No 44 Tahun 2014 (2014). Jakarta.

6. Kemenkes RI. (2018a). Simkespel. Jakarta.

7. Kemenkes RI. UU No.6 Tahun 2018 Tentang Kekarantinaan Kesehatan (2018). Indonesia.
8. Kemenkes RI, D. P. (2013). Pedoman Survei Entomologi Demam Berdarah Dengue dan Kunci Identifikasi Nyamuk Aedes. Jakarta.

9. KKP Kelas II Balikpapan. (2017). Profil Kantor Kesehatan Kelas II Balikpapan. Balikpapan.

10. Nadesul, H. (2016). Kiat Mengalahkan Demam Berdarah dan Virus Zika. Jakarta: PT. Kompas Media Nusantara.

11. Nani. (2016). Hubungan perilaku psn dengan keberadaan jentik aedes aegypti di pelabuhan pulang pisau. Jurnal Berkala Epidemiologi, 5 (January 2017).

https://doi.org/10.20473/jbe.v5i1.2017.1-12.

12. Novitasari, I., \& Sugiyanto, Z. (2014). Hubungan Suhu, Kelembaban Rumah Dan Perilaku Masyarakat Tentang PSN Dan Larvasidasi Dengan Keberadaan Jentik Nyamuk Penular Demam Berdarah Dengue Di Rw 01 Kelurahan Sendangguwo Semarang.

13. Praptowibowo, W. (2015). Maya Index dan Gambaran Habitat Perkembangbiakan Larva Aedes sp. Berdasarkan Endemisitas DBD di Kota Semarang Provinsi Jawa Tengah Wahyu Praptowibowo Fakultas Kesehatan Masyarakat Universitas Diponegoro Semarang Dengue haemorhagic fever (DHF) is an acu. Jurnal Kesehatan Masyarakat, 3(April).

14. Prasetyowati, H., \& Ginanjar, A. (2017). Maya Indeks dan Kepadatan Larva Aedes aegypti di Daerah Endemis DBD Jakarta Timur. Vektora, 9(1), 43-49.

15. PT Angkasa Pura I. (2018). Laporan Pergerakan Lalu Lintas Angkutan Udara.

16. Semenza, J. C., Sudre, B., Miniota, J., Rossi, M., Hu, W., Kossowsky, D., ... Khan, K. (2014). International Dispersal of Dengue through Air Travel: Importation Risk for Europe, 8(12). https://doi.org/10.1371/journal.pntd.0003278.

17. Septianto, A. (2014). Hubungan Antara Praktik Pemberantasan Sarang Nyamuk (PSN) Dengan Keberadaan Jentik Nyamuk Aedes Aegypti Di $R w \quad 7$ Kelurahan Sukorejo Kecamatan Gunungpati Kota Semarang.

18. Vyas, J. M. (2013). Medline Plus. Retrieved from 
http://www.nlm.nih.gov/medlineplus/ency/arti cle/001374.html. 